\title{
Potensi antitumor dari beberapa spons laut asal teluk Manado
}

\author{
Wilson A.R. Rombang* \\ Ilmu Kimia FMIPA, Universitas Negeri Manado, Tondano, 95619, Indonesia
}

\begin{tabular}{l} 
IN F O A R T I K E L \\
\hline Diterima 29 September 2017 \\
Disetujui 31 Oktober 2017 \\
\\
\hline Key word: \\
Antitumor, \\
marine sponge \\
\hline Kata kunci: \\
Antitumor, \\
Spons laut
\end{tabular}

\begin{abstract}
A B S T R A C T
Screening of antitumor for the extract and fraction from the marine sponges of Manado Gulf, Aaptos sp., Acervochalina sp., Gelliodes sp., Theonella sp., and orange boring sponge have been done by use P388 murine leukemia cell. Activity test result showed IC50 of the extract and fraction from Aaptos sp were: $\mathrm{MeOH}$ extract 5938 $\mathrm{ng} / \mathrm{mL}$ and $\mathrm{BuOH}$ extract $125000 \mathrm{ng} / \mathrm{mL}$; Acervochalina sp: EtOH extract 125000 $n g / m L$, PE extract $125000 \mathrm{ng} / \mathrm{mL}$, EtOAc extract $4251 \mathrm{ng} / \mathrm{mL}, \mathrm{BuOH}$ extract $125000 \mathrm{ng} / \mathrm{mL}$; Gelliodes sp: EtOH extract $125000 \mathrm{ng} / \mathrm{mL}$; Theonella sp: EtOH extract $125000 \mathrm{ng} / \mathrm{mL}$, PE extract $9282 \mathrm{ng} / \mathrm{mL}$, EtOAc extract $3273 \mathrm{ng} / \mathrm{mL}, \mathrm{BuOH}$ extract $125000 \mathrm{ng} / \mathrm{mL}$; orange boring sponge: $\mathrm{MeOH}$ extract $1422 \mathrm{ng} / \mathrm{mL}$. Based on the IC50 value, it could be concluded that $\mathrm{MeOH}$ extract of Aaptos sp., EtOAc extract of boring sponge could be a sources for cytotoxic compounds.
\end{abstract}

\section{A B STRAK}

Skrining antitumor ekstrak dan fraksi dari spons laut Teluk Manado, spons Aaptossp., Aervochalinasp., Gelliodessp., Theonellasp., dan boring spons warna oranye telah dilakukan menggunakan sel murin leukemia P388. Hasil uji aktivitas menunjukkan nilai IC 50 ekstrak dan fraksi dari spons Aaptos sp adalah ekstrak MeOH 5938 ng/mL dan ekstrak BuOH 125000 ng/mL; spons Achervochalina sp: EtOH 125000 ng/mL, ekstrak PE 125000 ng/mL, Ekstrak EtOAc $4251 \mathrm{ng} / \mathrm{mL}$, Ekstrak BuOH $125000 \mathrm{ng} / \mathrm{mL}$; spons theonella sp: ekstrak BuOH 125000 ng/mL, ekstrak PE 9282 ng/mL, ekstrak EtOAc 3273 ng/mL, ekstrak $\mathrm{BuOH} 125000 \mathrm{ng} / \mathrm{mL}$; spons boring (warna oranye): ekstrak $\mathrm{MeOH}$ $1422 \mathrm{ng} / \mathrm{mL}$. Berdasarkan nilai IC50 tersebut dapat disimpulkan bahwa ekstrak $\mathrm{MeOH}$ spons Aaptos sp., ekstrak EtOAc spons Acervochalina sp., ekstrak PE dan EtOAc spons Acervochalina sp., ekstrak PE dan EtOAc spons Theonella sp., dan ekstrak $\mathrm{MeOH}$ spons boring dapat dijadikan sebagai sumber senyawa sitotoksik.

\section{Pendahuluan}

Indonesia merupakan salah satu Negara yang kaya akan keanekaragaman hayati laut yang meliputi terumbu karang, spons, rumput laut, ikan dan jenis-jenis kerang. Luas terumbu karang di Indonesia diperkirakan sekitar 65.500 $\mathrm{kg}^{2}$, namun diperkirakan lebih dari $40 \%$ dalam kondisi buruk, 28\% dalam kondisi sedang dan $6 \%$ dalam kondisi baik [1]. Kerusakan terumbu karang akan menyebabkan kepunahan biota laut termasuk spons yang tidak bisa terbarukan karena spons dapat hidup dengan baik pada daerah terumbu karang. Melihat kondisi terumbu karang tersebut, diperlukan penanganan segera melalui kebijakan-kebijakan yang mengarah pada pelestarian terumbu karang dan penelitian tentang potensi biota laut diantaranya spons.

Spons banyak menghasilkan metabolit sekunder dengan struktur baru atau novel yang mempunyai aktivitas biologi beragam [2, 3]. Sampai saat ini penelitian tentang metabolit sekunder asal spons khususnya spons laut Indonesia relative masih kurang, padahal Indonesia merupakan Negara yang terkaya akan keanekaragaman spons [4]. Kanker atau tumor ganas adalah suatu penyakit yang disebabkan oleh pertumbuhan jaringan yang 
tidak normal akibat hilangnya mekanisme control sel. Ada beberapa faktor yang menyebabkan hilangnya mekanisme control sel diantaranya virus dan beberapa proses fisika dan kimia termasuk reaksi radikal bebas. Akibat adanya serangan dari faktor-faktor tersebut, suatu sel normal data mengalami transformasi menjadi sel kanker. Sel kanker yang terbentuk dapat membelah diri dan selanjutnya membentuk sel kanker yang lain.

Indonesia memiliki kekayaan biota laut yang melimpah diantaranya terumbu karang, spons, rumput laut, ikan dan jenis-jenis karang. Hal ini merupakan potensi yang perlu digali untuk dapat dimanfaatkan dalam rangka peningkatan ilmu pengetahuan dan kesejahteraan manusia sebelum kekayaan tersebut punah. Organisme lautan seperti spons merupakan salah satu sumber senyawa bioaktif dengan struktur baru atau novel yang mempunyai aktivitas biologi beragam $[2,3]$. Beberapa aktivitas biologi yang dimiliki oleh metabolit sekunder asal spons laut adalah penghambat aktivitas otot-otot halus vascular [5], antiviral, antitumor, antiinflamasi dan antibakteri [6], dan antioksidan [7].

\section{Bahan dan Metode}

Bahan spons yang digunakan dalam penelitian ini Aaptos sp., Acervovalina sp., Gelliodes sp., Spons boring Merah, Spons boring Orange, diambil dari Perairan Teluk Manado, Sulawesi Utara. Sampel spons kemudian dideterminasi di Pusat Penelitian OseanografiLembaga Ilmu Pengetahuan Indonesia (P2OLIPI). Bahan kimia yang digunakan adalah enzim P388, pereaksi-pereaksi untuk keprluan uji antitumor, dan pelarut-pelarut organik teknis dan pro analisis.

Ekstrasi Sampel segar spons Aaptos sp. (4000 g), Acervocalina sp. (1,1 kg) Gelliodes sp. (900 g), Theonella sp., (1000g), Spons boring Merah $(460 \mathrm{~g})$, Spons boring Orange (160 g), masingmasing dipotong tipis-tipis dan dimaserasi dengan etanol 95\% selama 3x 24 jam kemudian disaring. Filtratnya ditampung dan dievaporasi diperoleh ekstrak kental etanol Spons Aaptos sp. (638 g), Acervocalina sp. (46,93 g) Gelliodes sp. $(48,25 \mathrm{~g})$, Theonella sp. ( 48,70 g), Spons boring Oranye (11 g).

\section{Fraksionasi}

Sebanyak 200 gram ekstrak etanol spons Aaptos sp.dilarutkan dalam metanol-asam asetat (100:1) kemudian dipartisi dengan n-heksan diperoleh tiga lapisan : lapisan atas ( lapisan nheksan), lapisan tengah (lapisan metanol-asam), dan lapisan bawah (endapan). Lapisan metanolasam dievaporasi; diperoleh 80 gram ekstrat metanol-asam yang berwarnah coklat tua, berbentuk gum, dan berbau anyir ikan. Selanjutnya spons Acervocalina sp. (46,25 g), Gelliodes sp. (48,25 g), Theonella sp. (49,70 g), Spons boring Oranye (11 g). Ekstrak kental etanol Spons Acervocalina sp. (46,25 g), Gelliodes sp. $(48,25 \mathrm{~g})$, Theonella sp. $(49,70 \mathrm{~g})$, Spons boring Oranye (11 g) dilarutkan dalam metanol-air (95:5) kemudian disaring dan dipartisi dengan gradien kepolaran pelarut menggunakan petroleum eter, etil asetat, dan n-butanol. Masing-masing fraksi dievaporasi kemudian setiap fraksi diuji aktifitas sitotoksik.

\section{Uji Sitotoksik pada Sel P388}

Uji sitotoksik terhadap sel P388 dilakukan dalam tiga tahap : isolasi sel, multiplikasi dan uji hayati. Tahapan uji hayati dilakukan multi-well plate tissue cultur ( $1 \mathrm{~mL}$ cell/wel). Cuplikan dilarutkan dalam metanol dan dibuat dalam tiga variasi konsentrasi dan metanol $10 \mathrm{~mL}$ digunakan sebagai kontrol. Cuplikan dan kontrol ditambahkan pada sel dan diinkubasi selama 48 jam dalam inkubator $\mathrm{CO}_{2}$ pada suhu $37^{\circ} \mathrm{C}$. Selanjutnya, persen inhibisi dihitung menggunakan rumus:

$$
\% \text { inhibisi }=(1-\alpha) / \varepsilon \times 100
$$

Dimana $\alpha$ adalah jumlah sel yang hidup dalam cuplikan dan $\varepsilon$ adalah jumlah sel yang hidup dalam kontrol. Aktivitas inhibisi ditentukan dengan nilai IC $_{50}$ yaitu konsentrasi cuplikan $\left(\mu \mathrm{g} \mathrm{mL}^{-1}\right)$ yang menghibisi sel sejumlah 50\% selama inkubasi 48 jam.

\section{Hasil dan Pembahasan}

Bagian ini dapat dibagi kedalam beberapa subbagian. Subbagian tersebut harus memberikan deskripsi ringkas dan tepat tentang hasil eksperimen, interpretasi serta kesimpulan eksperimental yang dapat ditarik. 
Lima spesies spons Teluk Manado, Sulawesi Utara, Aaptos sp., Acervocalina sp., Gelliodes sp., Theonella sp., Spons boring Oranye dipilih untuk diteliti potensinya sebagai sumber senyawa antitumor. Kelima spesies spons dipilih secara acak diwaktu penyelam. Jumlah sampel spons segar yang dikumpulkan bervariasi antara 160 - 4000 gram (Tabel 1). Semua sampel dibersihkan kemudian dipotong tipis-tipis dan dimaserasi dengan etanol $95 \%$. Ekstraksi dilakukan pada seluruh bagian sampel spons. Hasil ekstraksi dengan etanol setelah dievaporasi 4,26 - 15,95 \% seperti yang ditunjukan pada Tabel 1.

Tabel 1. Jenis, jumlah sampel, dan hasil ekstraksi dengan etanol

\begin{tabular}{|c|c|c|c|c|}
\hline No & $\begin{array}{c}\text { Jenis Sampel } \\
\text { Spons }\end{array}$ & $\begin{array}{c}\text { Jumlah } \\
\text { Sampel } \\
\text { Segar } \\
\text { (gram }\end{array}$ & $\begin{array}{c}\text { Ekstrak } \\
\text { EtOH } \\
\text { (gram) }\end{array}$ & $\begin{array}{c}\text { Rendemen } \\
(\%)\end{array}$ \\
\hline 1. & Aaptos sp. & 4000 & 638,0 & 15,95 \\
\hline 2. & $\begin{array}{l}\text { Acervochalina } \\
\text { sp. }\end{array}$ & 1100 & 46,93 & 4,26 \\
\hline 3. & Theonella sp. & 1000 & 49,70 & 4,97 \\
\hline 4. & Gelliodes sp. & 900 & 48,25 & 5,36 \\
\hline 5. & $\begin{array}{l}\text { Spons Boring } \\
\text { Oranye }\end{array}$ & 160 & 11 & 6,87 \\
\hline
\end{tabular}

Fraksionasi setiap ekstrak kental etanol dilakukan dengan cara partisi pelarut mengguankan sistem gradien pelarut mulai dari pelarut nonpolar sampai pada pelarut polar yaitu petroleum eter dan n-heksan, etil asetat, dan n-butanol. Hasil partisi kemuadian di evaporasi untuk mendapatkan fraksi nheksan/p.e, etil asetat dan n-butanol dari masing-masing ekstrak etanol spons Aaptos sp., Acervocalina sp., Gelliodes sp., Theonella sp., Spons boring Oranye.

Untuk menentukan konsentrasi suatu ekstrak dinyatakan aktif atau tidak aktif sebagai penghambat P388 maka nilai IC 50 dari ekstrak yang diuji kurang dari atau sama dengan nilai pembanding kontrol yang memiliki $\mathrm{IC}_{50}<125000$ $\mathrm{ng} / \mathrm{ml}$. Hasil uji sitotoksik ekstrak kental etanol dari semua spons menunjukan IC $_{50}$ antara $1422 \mathrm{ng} / \mathrm{mL}$ (Tabel 2). Hasil uji tersebut menyatakan bahwa ekstrak kental etanol dari spons-spons tersebut bersifat aktif sitotoksik sehingga perlu dilakukan tahapan fraksionasi pada kesembilan ekstrak tersebut dengan panduan uji aktivitas.

Tabel 2. Nilais IC50 dari ekstrak etanol dan fraksi-fraksi

\begin{tabular}{|c|c|c|c|c|c|}
\hline \multirow{2}{*}{$\begin{array}{l}\mathrm{N} \\
\mathrm{O}\end{array}$} & \multirow{2}{*}{$\begin{array}{c}\text { Ekstrak } \\
\text { EtOH }\end{array}$} & \multicolumn{4}{|c|}{$\mathrm{IC}_{50}(\mathrm{ng} / \mathrm{mL})$} \\
\hline & & $\mathrm{EtOH}$ & $\begin{array}{c}\mathrm{n}- \\
\text { Heksa } \\
\mathrm{n}\end{array}$ & $\begin{array}{c}\text { EtOA } \\
c\end{array}$ & $\begin{array}{c}\mathrm{n}- \\
\mathrm{BuO} \\
\mathrm{H}\end{array}$ \\
\hline 1 & Aaptos sp. & $5938^{*}$ & $\mathrm{Nd}$ & nd & $\begin{array}{c}12500 \\
0\end{array}$ \\
\hline 2 & $\begin{array}{c}\text { Acervochali } \\
\text { na sp. }\end{array}$ & $\begin{array}{c}12500 \\
0\end{array}$ & $\begin{array}{c}12500 \\
0\end{array}$ & $4251^{*}$ & $\begin{array}{c}12500 \\
0\end{array}$ \\
\hline 3 & $\begin{array}{c}\text { Theonella } \\
\text { sp. }\end{array}$ & $\begin{array}{c}12500 \\
0\end{array}$ & $9282^{*}$ & $3273^{*}$ & $\begin{array}{c}12500 \\
0\end{array}$ \\
\hline 4 & $\begin{array}{c}\text { Gelliodes } \\
\text { sp. }\end{array}$ & $\begin{array}{c}12500 \\
0\end{array}$ & $\mathrm{Nd}$ & nd & nd \\
\hline 5 & $\begin{array}{c}\text { Spons } \\
\text { Boring } \\
\text { Oranye sp. }\end{array}$ & $1422^{*}$ & $\mathrm{Nd}$ & nd & nd \\
\hline
\end{tabular}

\section{Ucapan terimakasih}

Peneliti mengucapkan terima kasih kepada Universitas Negeri Manado yang telah mendanai penelitian ini melalui dana PNBP UNIMA.

\section{Kesimpulan}

Hasil uji sitotoksik untuk semua fraksi menunjukkan ekstrak MeOH spons Aaptos sp., EtOAc Acervochalina sp., PE Theonella sp. EtOAc Theonella sp., $\mathrm{MeOH}$ spons boring oranye berpotensi sebagai sumber senyawa aktif sitotoksik yang ditunjukkan dengan nilai IC $_{50}$ yang lebih rendah dengan pembanding.

\section{Daftar Pustaka}

1. Williams, L.; Wilkins, B., Kesadaran masyarakat tentang terumbu karang (kerusakan karang di Indonesia). P3O-LIPI, Indonesia: 1998.

2. Faulkner, D. J., Marine natural products. Natural product reports 2000, 17, (1), 7-55.

3. Blunt, J. W.; Copp, B. R.; Hu, W.-P.; Munro, M.; Northcote, P. T.; Prinsep, M. R., Marine natural products. Natural product reports 2007, 24, (1), 31-86.

4. Van Soest, R., The Indonesian sponge fauna: a status report. Netherlands Journal of Sea 
Research 1989, 23, (2), 223-230.

5. Nakamura, H.; Kobayashi, J. i.; Ohizumi, Y.; Hirata, Y., Aaptamines. Novel benzo [de][1, 6] naphthyridines from the Okinawan marine sponge Aaptos aaptos. Journal of the Chemical Society, Perkin Transactions 1 1987, 173-176.

6. Higa, T.; Tanaka, J.-1., Bioactive marine alkaloids from Okinawan waters. Chemistry and toxicology of diverse classes of alkaloids. Alaken Inc., Fort Collins, Colo 1996, 337-386.

7. Takamatsu, S.; Hodges, T. W.; Rajbhandari, I.; Gerwick, W. H.; Hamann, M. T.; Nagle, D. G., Marine natural products as novel antioxidant prototypes. Journal of natural products 2003, 66, (5), 605-608. 